\title{
Index Informativeness: An Empirical Study on Indonesia Stock Exchange
}

\author{
Heriyanto \\ Business and Accounting Faculty, Musi Charitas Catholic University \\ Email: heriyanto@ukmc.ac.id
}

\begin{abstract}
Abtsract: This study aims to determine the market's reaction to the announcement of company list change's at LQ45 Index, Jakarta Islamic Index (JII), and SRI-KEHATI Index. Sample of this research is company stocks that include in or exclude from LQ45 Index, JII, and SRI-KEHATI Index during the period 2009 to 2018. The results showed that in general in the sample group of companies included in the Index, no significant market reaction was found. For the sample group of companies excluded from the Index, significant negative market reactions were found from all the Index. Furthermore, there was no significant difference in market reaction was found, both in the sample group included and in the sample group excluded from the Index. Significant different market reaction were only found in the LQ45 Index and JII.
\end{abstract}

Keywords: Abnormal Return, Index Announcement.

Abstrak: Penelitian ini bertujuan untuk menguji reaksi pasar atas pengumuman pergantian daftar perusahaan di Indeks LQ45, Jakarta Islamic Index (JII), dan Indeks SRI-KEHATI. Sampel penelitian ini adalah saham-saham perusahaan yang masuk dan keluar dari Indeks LQ45, JII, dan Indeks SRI-KEHATI selama periode 2009 sampai dengan 2018. Hasil penelitian menunjukkan bahwa secara umum pada kelompok sampel perusahaan masuk ke dalam Indeks, tidak ditemukan adanya reaksi pasar yang signifikan. Adapun pada kelompok sampel perusahaan keluar dari Indeks, ditemukan adanya reaksi pasar yang negatif signifikan pada perusahaan yang keluar dari ketiga Indeks. Lebih lanjut, secara umum tidak ditemukan adanya perbedaan reaksi pasar yang signifikan, baik pada sampel kelompok masuk maupun sampel kelompok keluar, antara ketiga indeks. Perbedaan reaksi pasar yang signifikan hanya ditemukan pada Indeks LQ 45 dan JII.

Kata Kunci: Abnormal Return, Pengumuman Indeks.

\section{INTRODUCTION}

Index is a single number that describes the overall movement of data in a certain time period. Index is useful for simplifying information related to the overall movement of data. The index is used in various fields such as economics (business and trade), education, health, agriculture, and one of them is the capital market. There are various indices in the Indonesian Capital Market such as LQ45 Index, Jakarta Islamic Index, SRI-KEHATI Index, Kompas 100 Index, Bisnis-27 Index, PEFINDO25 Index and so on. The LQ45 Index, the Jakarta Islamic Index and the SRI-KEHATI index are indices that are often used as a reference for investors to make investment decisions. 
The LQ45 index is an index that measures the price performance of 45 stocks that have high liquidity and large market capitalization and are supported by good corporate fundamentals. The Jakarta Islamic Index is an index that measures the price performance of 30 Islamic stocks that have good financial performance and high transaction liquidity. Some of the criteria that must be met by shares to be able to enter the Jakarta Islamic Index are that the company's business does not violate Islamic principles (law), has a lawful income ratio, debt ratio, and several other criteria. SRI-KEHATI Index is an index that measures the performance of 25 listed companies that have well performed in fostering sustainable enterprises, as well as have an awareness of environmental, social, and good corporate governance called Sustainable and Responsible Investment (SRI). The SRI-KEHATI Index was launched and managed in collaboration with the Indonesian Biodiversity Foundation (KEHATI Foundation).

Evaluation of the list of companies included in the LQ45 Index, the Jakarta Islamic Index, and the SRI-KEHATI Index is carried out periodically, i.e. twice a year. The LQ 45 index is usually announced every January (valid for February to July) and July (valid for August to January). The Jakarta Islamic Index is usually announced in June (valid for July to December) and December (from January to June). Meanwhile, the SRI-KEHATI Index is usually announced in April (valid for May to October) and October (from November to April).

Figure 1. shows the phenomenon of changing company listings from the LQ45 Index, the Jakarta Islamic Index, and the SRI-KEHATI Index. Based on these data, it appears that the number of cases of company turnover is the most in the LQ45 Index and the SRIKEHATI Index compared to the Jakarta Islamic Index. The total cases of company name change in the LQ45 Index, the Jakarta Islamic Index, and the SRI-KEHATI Index are 94, 76 , and 99 companies respectively. The average cases of company name change in the LQ45 Index, the Jakarta Islamic Index, and the SRI-KEHATI Index are 9, 8, and 10 companies, respectively.

Figure 1. Number of Cases of Company List Change in Indexes in the Indonesian

Capital Market during the 2009-2018 Period

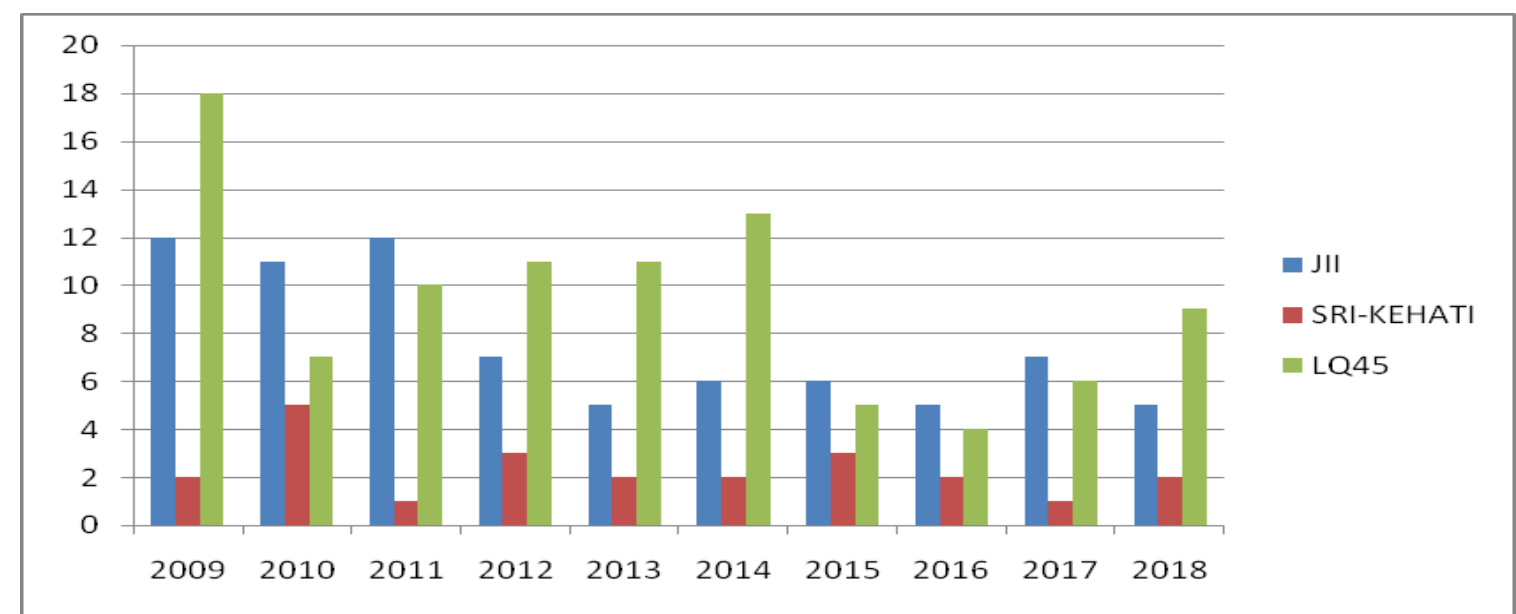

Source: (Data is processed from www.idx.co.id) 
Announcement of changes in the list of companies in the Index in the capital market is suspected to have information content so that investors will react to that information. Companies that are incorporated (entered) in an announcement of changes to the index company list are considered to have a positive reaction (considered as good news) while companies that exit in an announcement of changes in the index company list are considered to have a negative reaction (considered as bad news). According to (Yu et al., 2015), several previous studies have tried to prove this assumption with several explanations such as temporary price pressure factors, increased awareness from investors and analysts of shares included in the index, increased stock liquidity, improved performance (efforts) management company, and company performance improvement after addition to the index.

Previous studies have tested the market's reaction to the announcement of the entry and exit of company shares in an index. Some researchers conducted tests on several indices for large companies such as the Nasdaq 100 Index (Yu et al., 2015), the S\&P Index (Cai, 2007; Hrazdil and Scott, 2009; Jain, 1987; Elliot et al., 2006; Chen et al, 2004; Denis et al, 2003; Kamal et al., 2011; Marciniak, 2012; Marciniak and Smith, 2018), Nikkei Index (Okada et al, 2006), Dow Jones Index (Biktimirov and Xu, 2019), Athens Stock Exchange Index (ASE) (Papachristou et al., 2018), and ethical stock indexes such as Index of sustainability stock categories (Oberndorfer et al., 2013) and Indexes for Islamic stocks (Sayani and Balakrishnan, 2013; Mazouz et al., 2013;2019). Most of these studies generally find that the market reacts positively (negatively) to company stocks that enter (exit) on an Index. However, there is still relatively little research comparing the market reaction of incoming and outgoing stocks on indexes of companies with large market capitalization (non ethical stock) with ethical stock that refers to certain principles such as religious (for example sharia) and sustainable principles related with social and environmental issues. Previous studies related to this topic were limited to examining differences in the performance of company shares included in ethical stock and non-ethical stock (Heriyanto et al., 2019; Bennett and Zamir, 2013; BinMahfouz and Hassan, 2013; Bousalam and Hamzaoui, 2016 ; Diaz, 2016; and Karim et al., 2016).

This study develops previous research which also examines investor reactions to announcements of changes to the Index list. Specifically, this study uses a sample of company shares (in and out) in the Index with the concept of Social Responsible Investing, such as the Jakarta Islamic Index and the SRI-KEHATI Index, in addition to the LQ45 Index. This study will compare market reactions to events in and out of company shares in the LQ45 Index, JII, and the SRI-Kehati Index. Most of the previous studies only examined the market reaction to the entry and exit of company shares from the Index such as the Nasdaq, S\&P 500, and so on (without comparing market reactions to companies that enter and exit between indexes). Based on the descriptions in the previous section, this study is interested in testing how informative the index is in Indonesia Stock Exchange.

\section{THEORITICAL REVIEW}

Signaling Theory. According to (Josev et al., 2004), Economic signaling explains that there is asymmetric information (asymmetric information) where managers (insiders) have more superior (dominant) information compared to shareholders (shareholders) related to the company's future prospects. In this condition, managers have an incentive to take an action (decision) that has information content that can be relied on by investors in the capital 
market to maximize their welfare. In the event of information asymmetry, investors rely on information either published by the company or by other institutions that are trusted by investors. In the context of this research, information published and carried out by an institution is the announcement of a change in the list of companies included in a certain index in the capital market. Announcement of the change of company stock list includes shares of new companies (replacing the shares of previous companies), shares of companies that are still standing, and shares of companies that have just left (replaced by shares of new companies). The choice (entry) of a company's shares in a particular index list or the exit of a stock from a certain index list is associated with the existence of information content on the prospects of the company's financial performance in the future. The choice of a company in an index in the capital market is based on a number of criteria that must be met such as market capitalization of company shares, trading volume, to certain criteria including religious (for example sharia) principles such as the ratio of lawful and unlawful income, active companies do corporate social responsibility (CSR) on the environment (natural resources), and so on. Based on this, it can be estimated that the companies selected in a particular index is considered to have performance prospects are good in the future to come (good news), while companies that come out of a list of specified index is considered to have the prospect of poor performance in the future to come ( $\mathrm{bad}$ news).

In other contexts such as announcements of changes in company names, (Josev et al., 2004) in his research stated that information on changes in company names gives a strong signal to investors regarding the company's focus and direction of company orientation in the future. Because efforts to change a company's name require costs such as legality and accounting costs, advertising costs, and the possibility of losing market share due to changes in the company's image, the company must also have considered the benefits derived from changing the name. Conceptually, the company will change the name of the company with the belief that the company will get greater benefits compared to the costs incurred because of changing the name. Therefore, information on changing the name of the company is suspected to have positive information content.

Efficient Market Hypothesis. According (Tandelilin, 2010), markets are efficient is the market where all securities prices already reflect all information that is available. In the field of finance itself, an efficient market is more viewed in terms of information alone. Information market efficiency is the relationship between the price of a security and information. According (Tandelilin, 2010) capital markets efficiently divided into three levels, namely: market efficient form of weak (weak form) (all information in the past (historical) will be reflected in the prices established now. Therefore, historical information that, (share prices, trading volumes and past events) can no longer be used to predict future price changes ); Efficient market in the form of half strong (semi strong); ( Meaning the price of a stock market that is formed now has reflected the historical information coupled with all of the information published (earnings, dividends, announcements of stock splits, issuance of new shares, financial difficulties were experienced by the company, and events published more impact on the company's cash flow in the future); market efficient form of strong (strong form) ( means the market price of the stock that is formed now has reflected the historical information plus and all information published coupled with unpublished information. Thus, in the form of the efficient market there would not be an investor else who could obtain the return is not normal (abnormal returns)). In the context of the research 
it, test market reaction to the announcement of the change list of companies in the LQ45 index and index are included in the Social Responsible Investing (Jakarta Islamic Index and Index SRI-KEHATI) are included in capital market testing forms efficient half strong because this research examines the market reaction to the information content published in the capital market.

Market Reaction to the Announcement of Substitution of firm in an Index. The change in the list of company shares in an index follows certain criteria that are set. Companies that are included in the stock list of an index are considered as a company (performance) that is able to meet a number of predetermined criteria. Conversely, a company that exits an index stock list is considered as a form of failure of a company in maintaining (fulfilling) a number of predetermined criteria. In summary, the announcement on the inclusion of a stock company into an index regarded as good news (good news) which is perceived as the outlook for the company's financial performance in the period ahead. Conversely, announcements of a company's shares being released from an index list are considered bad news on the prospects of the company's financial performance in the future. Jain (1987) in his research using the S\&P 500 Index found the results of the study that there was a positive (negative) significant reaction on shares of companies that entered (exited) from the S\&P 500 Index. Denis et al (2003) in his research on the relationship of firm that included and excluded from the S\&P 500 Index with an increase in corporate profits found the results that companies that were newly included in the S\& P500 Index experienced an increase in earnings.

This can occur because the inclusion of company shares in the S\&P 500 Index is associated with an increase in management in managing operational activities which ultimately impact on increasing company profits. (Chen et al., 2004) in their research on market reaction to the entry and exit of company shares from the S\&P 500 index showed that there was a permanent positive reaction to the announcement of the company's shares entering the index, while negative permanent reactions were not found in the case of shares leaving the index. (Okada et al., 2006) in their study of the market reaction to the inclusion of company shares in the Nikkei 225 Index on the capital market in Japan found that there was a positive market reaction. The increasing positive cumulative abnormal return of the company shows that there is demand shock on the company's shares included in the Nikkei 225 Index. The results of this study are consistent with the hypothesis that an increase in demand for company shares included in the Index causes the stock price to increase. Furthermore, (Okada et al., 2006) show that the positive reaction of this stock is relatively temporary (temporary) because after the effective date of the change in the list of company shares included in the Index, the company's share price has decreased. (Cai, 2007) in his research on market reaction to the announcement of a stock entry information in the S\&P 500 index found that there was a positive reaction.

Furthermore, (Cai, 2007) also found that market reactions also occurred in other companies in one industrial sector with companies included in the index. The direction of the reaction on a competitor (rival) depends on the size (characteristics) of the rival company. (Hrazdil and Scott, 2009) find that there is a positive market reaction to the announcement of the entry of a company into the S \& P500 Index. Furthermore, (Hrazdil and Scoot, 2009) found that unexpected earnings of companies included in the S \& P500 Index had increased. Companies that are included in the Index have access to capital, which 
has an impact on improving the company's financial performance. (Marciniak, 2012) also found a positive market reaction to the announcement of the entry of a company's shares into the S \& P400 Index. The (Marciniak, 2012) explains the market reaction to information relies heavily on published information, mode (type of) the addition, exchange listing, the reason for the change index, and the size of the company are included in the index. Marciniak also shows that the market reaction also occurs in others company (rival) who are in the same industry with companies that included into the index. (Yu et al., 2015) in their research on market reaction to the announcement of the entry of a stock into the Nasdaq-100 Index shows that there is a positive market reaction to the company's shares that enter the index. Furthermore, (Yu et al., 2015) examined the factors that explain the occurrence of a positive market reaction on company stocks that enter the index. (Yu et al., 2015) found that the influencing factor was due to the increased attention (awareness) of analysts on the company's shares so that in the end it had an impact on increasing company liquidity. (Qiu and Pinfold, 2007) in their research on companies that enter and exit the S\&P Index (ASX100 and ASX300) in Australia show that there is generally no market reaction to changes in the list of companies (in and out) of the S\&P Index.

There is only weak evidence of market reaction to the company's shares that enter the Index (by 1.06\%) and exit the Index (2.78\%). (Qiu and Pinfold, 2007) state that the results of their research are consistent with the results of previous studies which show that market reactions to the entry and exit of company stocks from the Index are relatively smaller for studies outside the United States. (Kamal et al., 2011) examined the differences in market reaction to the inclusion of company shares in the S\&P 500 Index before and after 2000. The results of the study showed that after 2000 there was a decline in information asymmetry that caused the average abnormal return of company shares included in the index to be relatively smaller (decreased) compared to the period before 2000. Furthermore, (Kamal et al., 2011) also showed that after 2000, there was no visible change in liquidity in companies that entered the S\&P 500 Index. Oberndorfer et al (2013) in his research regarding the shares of companies in Germany included in the sustainability stock index found that there was a negative reaction to the event. Oberndorfer et al (2013) further stated that this implies that investors do not reward (rewarded) companies that have higher social (environmental) performance (which can actually potentially benefit from a better company reputation and cost savings in long-term). Sayani and Balakrishnan (2013) examined the performance of company shares in the KMI30 Index on the Karachi Stock Exchange. The results of his research show that company shares included in the KMI30 Index have a positive market return and a relatively low level of stock volatility when compared to the KSE100 Index. Biktimirov and Li (2014) in their study of changes in companies moving from the FTSE SmallCap Index to the FTSE LargeCap Index (and vice versa) found that companies that moved from the FTSE SmallCap Index to the FTSE LargeCap Index experienced a permanent increase in share prices, in contrast companies that left the FTSE LargeCap Index to FTSE SmallCap Index experienced a permanent decline in stock prices. The results of his research support the liquidity hypothesis and price pressure hypothesis.

Biltimirov and $\mathrm{Xu}$ (2019) examine the market reaction to changes in the list of companies in the Dow Jones Industrial Average Index. Specifically, Biltimirov and Xu (2019) in their research used a relatively long research period, namely 1929-2015. The results of his research indicate that there is a positive (negative) market reaction to the 
announcement of the entry (exit) of company shares from the Index. Significant abnormal returns are caused by an increase (decrease) in the trading volume of a company's shares ( 2 days before the effective day of the event and on the day of the event) entering (exiting) the Index. Biltimirov's research supports the liquidity hypothesis and does not support the price pressure hypothesis, the downward-sloping demand curve, the information cost hypothesis, and the investor awareness hypothesis.

Mazouz et al (2019) in his research tested the short-term impact on the company's stock price included in the revised Dow Jones Islamic Market World Index (DJIMWI) every quarter. Using a sample of 8,250 shares during the May 1999 to June 2012 period, the results of Mazouz et al (2019) showed that there was a significant market reaction to companies entering and leaving DJIMWI. Specifically, Mazouz et al (2019) found that there was a positive (negative) reaction to company announcements coming in (out) from DJIMWI. Furthermore, Mazouz et al (2019) states that this reaction is greater than the research conducted on developing capital markets. Mazouz et al (2019) also found that the reaction that occurs is caused more by changes in investor sentiment (perceptions) of company shares entering or leaving the index than due to changes in the company's financial performance. Marciniak and Smith (2018) examine the market reaction to the announcement of the entry of companies in the S\&P 500 Index associated with uncertainty related to company conditions and capital market conditions. The results of his research show that the strength of market reactions to company shares varies depending on uncertainty on investor perceptions.

Companies with lower market capitalization compared to the Index, have a higher total risk, relatively lower trading volume, and for the first time in the S\&P Index tend to get a more positive reaction than companies that have the opposite character (lower level of company insecurity ). Papachristou et al (2018) tested the market reaction to the entry and exit of company shares from the FTSE-ASE 20 Index on the Athens Stock Exchange. Papachristou et al (2018) found that companies leaving the index experienced significant negative reactions and even these negative reactions lasted more than 15 days. As for the case of companies included in the index, Papachristou et al (2018) found that there is a positive market reaction but takes place in the short term.

In this regard, the announcement of a change of company listings in an index is seen as a signal of confidence for investors over the prospects of the company's financial performance in the future.

H1: There is a positive market reaction to the announcement of the entry of company shares into the LQ45 Index and Index that are included in the Social Responsible Investing (Jakarta Islamic Index and SRI-KEHATI Index)?

H2: There is a negative market reaction to the announcement of the release of the company's shares from LQ45 index list and index that are excluded from the Social Responsible Investing (Jakarta Islamic Index and Index SRI-KEHATI)

H3: There is a significant difference in market reaction between the announcement of company shares that enter the LQ45 Index list and the stock index included in the Social Responsible Investing (Jakarta Islamic Index and SRI-KEHATI Index). 
H4: There is a significant difference in market reaction between announcements of company stocks that are out of the LQ45 Index list and stock indexes that are excluded from Social Responsible Investing (Jakarta Islamic Index and SRI-KEHATI Index).

\section{METHODOLOGY}

This research is quantitative research. This study is intended to confirm the hypothesis of the study through the processing of the data sample statistically. Specifically, this study uses an event study approach. This study intends to examine the market reaction to the announcement of company stock that are included and excluded from LQ45 Index, JII, and the SRI-Kehati Index.

The population of this study are all companies that included and excluded from LQ45 Index, the Jakarta Islamic Index, and the SRI-KEHATI Index during the period 2009 to 2018. The sample selection in this study uses a purposive sampling method with the following criteria: the company has complete daily closing stock price data during the estimated period (100 days of observation before the testing period) and the testing period ( 5 days before, during, and 5 days after the announcement), the company does not announce or carry out other corporate actions that have a material impact on the company's share price such as stock split, rights issue, dividend distribution, and so on, in the testing period that are same, there should be no more than 1 case announcements (both of information about stock that are included or excluded from the index), companies active transact at least 30 active trading days from the entire estimated period (100 days).

Based on the sample criteria above, we obtain the sample as shown in table 1, table 2, and table 3 as follows:

Table 1.

The Company Sampling Process that Include In and Exclude From LQ45 Index During the 2009-2018

\begin{tabular}{c|c|c}
\hline \multicolumn{3}{c}{ LQ45 Index Registered Company Sample } \\
\hline Information & $\begin{array}{c}\text { Sample Group } \\
\text { Enter Index }\end{array}$ & $\begin{array}{c}\text { Sample Group } \\
\text { Exit Index }\end{array}$ \\
\hline Number of initial samples & 94 & 94 \\
\hline $\begin{array}{c}\text { The company has complete daily closing stock } \\
\text { price data for the estimated period }\end{array}$ & $(1)$ & $(1)$ \\
\hline $\begin{array}{c}\text { The company does not announce or carry out } \\
\text { other corporate actions that have a material } \\
\text { impact on the company's stock prices such as } \\
\text { stocksplit, right issues, dividend distribution, and } \\
\text { so on }\end{array}$ & $(10)$ & $(12)$ \\
\hline $\begin{array}{c}\text { In the testing period are the same, there should } \\
\text { be no more than 1 case announcement. }\end{array}$ & 0 & 0 \\
\hline $\begin{array}{c}\text { Active companies transact at least 30 active } \\
\text { trading days from the entire estimated period }\end{array}$ & 0 & 0 \\
\hline Number of final samples & 83 & 81 \\
\hline
\end{tabular}

Source: (data processed, 2020) 
Table 2.

The The Company Sampling Process that Include In and Exclude From Jakarta Islamic Index During the 2009-2018

\begin{tabular}{c|c|c}
\hline \multicolumn{1}{c}{ Sample of Registered Company of the Jakarta Islamic Index } \\
\hline Information & $\begin{array}{c}\text { Sample Group } \\
\text { Enter Index }\end{array}$ & $\begin{array}{c}\text { Sample Group } \\
\text { Exit Index }\end{array}$ \\
\hline Number of initial samples & 76 & 76 \\
\hline $\begin{array}{c}\text { The company has complete daily closing stock } \\
\text { price data for the estimated period }\end{array}$ & 0 & 0 \\
\hline $\begin{array}{c}\text { The company does not announce or carry out } \\
\text { other corporate actions that have a material impact } \\
\text { on the company's stock prices such as stocksplit } \\
\text { right issues, dividend distribution, and so on }\end{array}$ & $(36)$ & $(38)$ \\
\hline $\begin{array}{c}\text { In the testing period are the same, there should be } \\
\text { no more than 1 case announcement. }\end{array}$ & 0 & 0 \\
\hline $\begin{array}{c}\text { Active companies transact at least 30 active } \\
\text { trading days from the entire estimated period }\end{array}$ & 0 & 0 \\
\hline Number of final samples & 40 & 38 \\
\hline
\end{tabular}

Source: (data processed, 2020)

Table 3.

The Company Sampling Process that Include In and Exclude From SRI-KEHATI Index During the 2009-2018

\begin{tabular}{c|c|c}
\hline \multicolumn{3}{c}{ Sample Company Registered SRI-KEHATI Index } \\
\hline Information & $\begin{array}{c}\text { Sample Group } \\
\text { Enter Index }\end{array}$ & $\begin{array}{c}\text { Sample Group Exit } \\
\text { Index }\end{array}$ \\
\hline $\begin{array}{c}\text { Number of initial samples } \\
\text { The company has complete daily closing stock } \\
\text { price data for the estimated period }\end{array}$ & 23 & 23 \\
\hline $\begin{array}{c}\text { The company does not announce or carry out } \\
\text { other corporate actions that have a material } \\
\text { impact on the company's stock prices such as } \\
\text { stocksplit, right issues, dividend distribution, } \\
\text { and so on }\end{array}$ & $(10)$ & $(0)$ \\
\hline $\begin{array}{c}\text { In the testing period are the same, there should } \\
\text { be no more than 1 case announcement. }\end{array}$ & 0 & $(10)$ \\
\hline $\begin{array}{c}\text { Active companies transact at least 30 active } \\
\text { trading days from the entire estimated period }\end{array}$ & 0 & 0 \\
\hline Number of final samples & 13 & 13 \\
\hline
\end{tabular}

Source: (data processed, 2020)

This research uses secondary data. The testing period for announcement information content is 11 days ( 5 days before, at the time of, and 5 days after the announcement date of 
the company's delisting). Data that used in this study is company's daily stock price. The data for announcing changes in the list of companies in LQ45, JII, and SRI-Biodiversity Index is accessible from www.idx.co.id . Other corporate action data conducted by the company such as dividend distribution, stock split, right offering, mergers and acquisitions, etc. can be accessed from www.ksei.co.id . The market reaction to the announcement of changes in the list of companies in the index is measured by abnormal returns using market model.

This study uses documentation techniques in data collection. The data source is information on announcements of changes in the list of companies in the index through www.idx.co.id , corporate action data on companies through www.ksei.co.id, data on the company's daily closing stock price through www.finance.yahoo.com .

Variable dependent in this research is abnormal return. Abnormal return is the difference between the actual return that occurs and expected returns. The calculations are as follows:

$$
R T N_{i, t}=R_{i, t}-E\left(R_{i, t}\right)
$$

Note :

$\mathrm{RTNi}, \mathrm{t}=$ abnormal return of the stock-i on the day- $\mathrm{t}$

$\mathrm{Ri}, \mathrm{t} \quad=$ actual return for stock-i on the day- $\mathrm{t}$

$\mathrm{E}(\mathrm{Ri}, \mathrm{t}) \quad=$ expected return for the the stock-i on the

day-t

Actual returns are returns that occurred on the day all $t$ which states the difference between the current price relative to the price of the previous period, calculated by the formula:

$R_{i, t}=\frac{P_{t}-P_{t-1}}{P_{t-1}}$

Note:

$\mathrm{Ri}, \mathrm{t}=$ actual return for stock-i on the day- $\mathrm{t}$

$\mathrm{Pt} \quad=$ closing stock price on day $\mathrm{t}$

Pt-1 = closing price on day $\mathrm{t}-1$

While the return expectations ( expected return ) represents the return expectations of investors. In this study, expected return is obtained using the market model method.

This study uses the mean difference test of one group (testing one sample t-test) to test hypotheses 1 and 2 and the mean difference test of two groups of independent (independent $t$-test). Statistical testing of each period by using t-arithmetic aims to test the significance of the company's abnormal stock returns .

Descriptive statistics. Based on table 4, it can be seen that the mean abnormal return value of the companies included in the LQ45 Index from t-5 to t- 1 is negative, while the mean abnormal return value from $t 0$ to $t+5$ has a majority of positive values. The lowest abnormal 
return value is at $t+5$, which is $-18.25 \%$ and the highest abnormal return value is at $t+4$, which is equal to $21.42 \%$. The largest standard deviation of the company's abnormal returns is at $\mathrm{t}+2$, which is $4.18 \%$. Based on table 5 , it can be seen that the mean abnormal return value of the company coming out of the LQ45 Index from t-4 to t-2 is positive, while the mean abnormal return value from $t-1$ to $t+4$ has a majority of negative values. The lowest abnormal return value is at $t 0$, which is $-40.55 \%$ and the highest abnormal return value is at $\mathrm{t}+5$, which is equal to $24.87 \%$. The biggest standard deviation of the company's abnormal returns is at $\mathrm{t} 0$, which is $5.69 \%$.

Table 4.

Descriptive Statistics of Abnormal Return Data of Companies Included in the LQ45 Index for the period 2009 - 2018

\begin{tabular}{c|c|c|c|c}
\hline Period & Mean & Min & Max & Std Deviation \\
\hline $\mathrm{t}-5$ & $-0,0060$ & $-0,1080$ & 0,0950 & 0,0310 \\
\hline $\mathrm{t}-4$ & $-0,0018$ & $-0,0701$ & 0,0949 & 0,0275 \\
\hline $\mathrm{t}-3$ & $-0,0007$ & $-0,0793$ & 0,1179 & 0,0311 \\
\hline $\mathrm{t}-2$ & $-0,0088$ & $-0,1238$ & 0,0741 & 0,0272 \\
\hline $\mathrm{t}-1$ & $-0,0065$ & $-0,1320$ & 0,0868 & 0,0315 \\
\hline $\mathrm{t} 0$ & 0,0032 & $-0,0826$ & 0,1754 & 0,0359 \\
\hline $\mathrm{t}+1$ & $-0,0049$ & $-0,1518$ & 0,1083 & 0,0401 \\
\hline $\mathrm{t}+2$ & 0,0022 & $-0,1862$ & 0,1517 & 0,0418 \\
\hline $\mathrm{t}+3$ & 0,0028 & $-0,1127$ & 0,1236 & 0,0334 \\
\hline $\mathrm{t}+4$ & 0,0004 & $-0,1326$ & 0,2142 & 0,0390 \\
\hline $\mathrm{t}+5$ & $-0,0077$ & $-0,1825$ & 0,0571 & 0,0384 \\
\hline $\mathrm{t}(-1,0)$ & $-0,0033$ & $-0,2146$ & 0,1885 & 0,0553 \\
\hline $\mathrm{t}-(1,+1)$ & $-0,0082$ & $-0,3120$ & 0,1573 & 0,0772 \\
\hline $\mathrm{t}(-1,+5)$ & $-0,0104$ & $-0,6835$ & 0,3101 & 0,1577 \\
\hline $\mathrm{t}(-5,+5)$ & $-0,0278$ & $-0,9859$ & 0,3557 & 0,2168 \\
\hline $\mathrm{S}$ & \multicolumn{2}{|c}{}
\end{tabular}

Source: (processed data, 2020)

Table 5.

Descriptive Statistics of Abnormal Return Data of Companies Excluded from the LQ45 Index for the period 2009 - 2018

\begin{tabular}{c|c|c|c|c}
\hline Period & Mean & Min & Max & Std Deviation \\
\hline $\mathrm{t}-5$ & $-0,0040$ & $-0,0642$ & 0,0401 & 0,0202 \\
\hline $\mathrm{t}-4$ & 0,0032 & $-0,0527$ & 0,1063 & 0,0276 \\
\hline $\mathrm{t}-3$ & 0,0037 & $-0,0838$ & 0,0880 & 0,0271 \\
\hline $\mathrm{t}-2$ & 0,0025 & $-0,0579$ & 0,0989 & 0,0254 \\
\hline $\mathrm{t}-1$ & $-0,0011$ & $-0,1060$ & 0,0779 & 0,0277 \\
\hline $\mathrm{t} 0$ & $-0,0047$ & $-0,4055$ & 0,1812 & 0,0569 \\
\hline $\mathrm{t}+1$ & $-0,0058$ & $-0,1620$ & 0,2114 & 0,0419 \\
\hline $\mathrm{t}+2$ & 0,0000 & $-0,0719$ & 0,1005 & 0,0272 \\
\hline $\mathrm{t}+3$ & $-0,0042$ & $-0,0762$ & 0,0985 & 0,0304 \\
\hline
\end{tabular}




\begin{tabular}{c|c|c|c|c}
\hline $\mathrm{t}+4$ & $-0,0012$ & $-0,0890$ & 0,1648 & 0,0380 \\
\hline $\mathrm{t}+5$ & 0,0053 & $-0,1125$ & 0,2487 & 0,0503 \\
\hline $\mathrm{t}(-1,0)$ & $-0,0058$ & $-0,4165$ & 0,2092 & 0,0675 \\
\hline $\mathrm{t}-(1,+1)$ & $-0,0116$ & $-0,4265$ & 0,4206 & 0,0845 \\
\hline $\mathrm{t}(-1,+5)$ & $-0,0117$ & $-0,4759$ & 0,4014 & 0,1234 \\
\hline $\mathrm{t}(-5,+5)$ & $-0,0062$ & $-0,5174$ & 0,4757 & 0,1458 \\
\hline
\end{tabular}

Source: (processed data, 2020)

Based on table 6, it appears that the mean abnormal return value of companies included in JII from t-5 to t- 1 is mostly negative, while the mean abnormal return from t0 to $t+5$ is positive. The lowest abnormal return value is found at $t+3$, which is equal to $16.26 \%$ and the highest abnormal return value is found at $t+2$, which is equal to $19.94 \%$. The largest standard deviation of the company's abnormal returns is at $t+2$, which is $4.41 \%$.

Based on table 7, it appears that the mean abnormal return value of the company that comes out of JII from t-3 to $t+4$ is mostly negative, while the mean abnormal return value from $\mathrm{t}-5$ to $\mathrm{t}-4$ is positive. The lowest abnormal return value is at $\mathrm{t}+5$, which is $-10.74 \%$ and the highest abnormal return value is at $\mathrm{t}-5$, which is equal to $27.94 \%$. The largest standard deviation of the company's abnormal returns is at $\mathrm{t}-5$, which is $4.78 \%$.

Table 6.

Descriptive Statistics of Abnormal Return Data of Companies Included in the JII Index for the period $2009-2018$

\begin{tabular}{c|c|c|c|c}
\hline Period & Mean & Min & Max & Std Deviation \\
\hline $\mathrm{t}-5$ & $-0,0047$ & $-0,0594$ & 0,0657 & 0,0223 \\
\hline $\mathrm{t}-4$ & $-0,0073$ & $-0,0595$ & 0,0793 & 0,0276 \\
\hline $\mathrm{t}-3$ & $-0,0056$ & $-0,0884$ & 0,0416 & 0,0250 \\
\hline $\mathrm{t}-2$ & 0,0095 & $-0,0496$ & 0,1166 & 0,0277 \\
\hline $\mathrm{t}-1$ & $-0,0023$ & $-0,0639$ & 0,0529 & 0,0225 \\
\hline $\mathrm{t} 0$ & 0,0058 & $-0,0363$ & 0,1490 & 0,0309 \\
\hline $\mathrm{t}+1$ & 0,0124 & $-0,0442$ & 0,1361 & 0,0344 \\
\hline $\mathrm{t}+2$ & 0,0108 & $-0,0795$ & 0,1994 & 0,0441 \\
\hline $\mathrm{t}+3$ & $-0,0066$ & $-0,1626$ & 0,1142 & 0,0391 \\
\hline $\mathrm{t}+4$ & 0,0064 & $-0,0447$ & 0,0833 & 0,0263 \\
\hline $\mathrm{t}+5$ & 0,0032 & $-0,0485$ & 0,0962 & 0,0282 \\
\hline $\mathrm{t}(-1,0)$ & 0,0035 & $-0,0630$ & 0,1360 & 0,0394 \\
\hline $\mathrm{t}-(1,+1)$ & 0,0159 & $-0,0948$ & 0,2274 & 0,0605 \\
\hline $\mathrm{t}(-1,+5)$ & 0,0297 & $-0,1345$ & 0,2278 & 0,0768 \\
\hline $\mathrm{t}(-5,+5)$ & 0,0215 & $-0,1470$ & 0,2345 & 0,0898 \\
\hline
\end{tabular}

Source: (processed data, 2020)

Table 7.

Descriptive Statistics of Abnormal Return Data of Companies Excluded from the JII for the period $2009-2018$

\begin{tabular}{c|c|c|c|c}
\hline Period & Mean & Min & Max & Std Deviation \\
\hline $\mathrm{t}-5$ & 0,0119 & $-0,0291$ & 0,2794 & 0,0478 \\
\hline
\end{tabular}




\begin{tabular}{c|c|c|c|c}
\hline $\mathrm{t}-4$ & 0,0028 & $-0,0375$ & 0,0869 & 0,0245 \\
\hline $\mathrm{t}-3$ & $-0,0076$ & $-0,0580$ & 0,0327 & 0,0188 \\
\hline $\mathrm{t}-2$ & $-0,0022$ & $-0,0691$ & 0,0701 & 0,0229 \\
\hline $\mathrm{t}-1$ & $-0,0081$ & $-0,0545$ & 0,0489 & 0,0221 \\
\hline $\mathrm{t} 0$ & $-0,0026$ & $-0,0424$ & 0,0444 & 0,0171 \\
\hline $\mathrm{t}+1$ & $-0,0022$ & $-0,0392$ & 0,0571 & 0,0215 \\
\hline $\mathrm{t}+2$ & $-0,0046$ & $-0,0404$ & 0,0496 & 0,0158 \\
\hline $\mathrm{t}+3$ & 0,0008 & $-0,0515$ & 0,0936 & 0,0249 \\
\hline $\mathrm{t}+4$ & $-0,0021$ & $-0,0345$ & 0,0343 & 0,0142 \\
\hline $\mathrm{t}+5$ & 0,0028 & $-0,1074$ & 0,0760 & 0,0302 \\
\hline $\mathrm{t}(-1,0)$ & $-0,0107$ & $-0,0794$ & 0,0933 & 0,0300 \\
\hline $\mathrm{t}(-1,+1)$ & $-0,0130$ & $-0,1017$ & 0,0540 & 0,0364 \\
\hline $\mathrm{t}(-5,+5)$ & $-0,0159$ & $-0,2342$ & 0,0901 & 0,0589 \\
\hline $\mathrm{S}$ & $-0,0111$ & $-0,4200$ & 0,2653 & 0,0945 \\
\hline
\end{tabular}

Source: (processed data, 2020)

Based on table 8 , it can be seen that the mean abnormal return value of the company included in the SRI-KEHATI Index from $t-5$ to $t+5$ is negative. The lowest abnormal return value is at $\mathrm{t}+1$, which is $-40.49 \%$ and the highest abnormal return value is at $\mathrm{t}+1$, which is $6.96 \%$. The largest standard deviation of the company's abnormal returns is at $t+1$, which is $11.56 \%$.

Based on table 9, it appears that the mean abnormal return value of the companies included in the LQ45 Index from t-5 to t0 is mostly negative, while the mean abnormal return value from $\mathrm{t}+1$ to $\mathrm{t}+4$ is mostly positive. The lowest abnormal return value is at $\mathrm{t}$ +2 , which is $-8.91 \%$ and the highest abnormal return value is at $t+1$, which is equal to $16.84 \%$. The largest standard deviation of the company's abnormal returns is at $t+1$, which is $5.47 \%$.

Table 8.

Descriptive Statistics of Abnormal Return Data of Companies Included in the SRIKEHATI Index for the Period 2009 - 2018

\begin{tabular}{c|c|c|c|c}
\hline Period & Mean & Min & Max & Std Deviation \\
\hline $\mathrm{t}-5$ & $-0,0318$ & $-0,3645$ & 0,0141 & 0,1006 \\
\hline $\mathrm{t}-4$ & $-0,0291$ & $-0,3620$ & 0,0390 & 0,1014 \\
\hline $\mathrm{t}-3$ & $-0,0266$ & $-0,3645$ & 0,0563 & 0,1045 \\
\hline $\mathrm{t}-2$ & $-0,0212$ & $-0,3251$ & 0,0595 & 0,0941 \\
\hline $\mathrm{t}-1$ & $-0,0287$ & $-0,3642$ & 0,0537 & 0,1026 \\
\hline $\mathrm{t} 0$ & $-0,0323$ & $-0,3654$ & 0,0040 & 0,1004 \\
\hline $\mathrm{t}+1$ & $-0,0343$ & $-0,4049$ & 0,0696 & 0,1156 \\
\hline $\mathrm{t}+2$ & $-0,0359$ & $-0,3665$ & 0,0290 & 0,1019 \\
\hline $\mathrm{t}+3$ & $-0,0262$ & $-0,3666$ & 0,0235 & 0,1028 \\
\hline $\mathrm{t}+4$ & $-0,0298$ & $-0,3636$ & 0,0197 & 0,1013 \\
\hline $\mathrm{t}+5$ & $-0,0271$ & $-0,3634$ & 0,0395 & 0,1022 \\
\hline $\mathrm{t}(-1,0)$ & $-0,0610$ & $-0,7297$ & 0,0376 & 0,2016 \\
\hline $\mathrm{t}(-1,+1)$ & $-0,0953$ & $-1,1346$ & 0,0450 & 0,3142 \\
\hline $\mathrm{t}(-5,+5)$ & $-0,2144$ & $-2,5947$ & 0,0445 & 0,7166 \\
\hline $\mathrm{Source}(\mathrm{pr}-0,3231$ & $-4,0109$ & 0,1086 & 1,1101 \\
\hline
\end{tabular}

Source: (processed data, 2020) 
Table 9.

Descriptive Statistics of Abnormal Return Data of Companies Ecluded from the SRIKEHATI Index for the Period 2009 - 2018

\begin{tabular}{c|c|c|c|c}
\hline Period & Mean & Min & Max & Std Deviation \\
\hline $\mathrm{t}-5$ & $-0,0038$ & $-0,0443$ & 0,0425 & 0,0233 \\
\hline $\mathrm{t}-4$ & $-0,0023$ & $-0,0285$ & 0,0281 & 0,0143 \\
\hline $\mathrm{t}-3$ & $-0,0032$ & $-0,0405$ & 0,0168 & 0,0145 \\
\hline $\mathrm{t}-2$ & 0,0074 & $-0,0102$ & 0,0591 & 0,0199 \\
\hline $\mathrm{t}-1$ & $-0,0022$ & $-0,0170$ & 0,0170 & 0,0100 \\
\hline $\mathrm{t} 0$ & $-0,0060$ & $-0,0331$ & 0,0204 & 0,0144 \\
\hline $\mathrm{t}+1$ & 0,0031 & $-0,0465$ & 0,1684 & 0,0547 \\
\hline $\mathrm{t}+2$ & $-0,0156$ & $-0,0891$ & 0,0270 & 0,0326 \\
\hline $\mathrm{t}+3$ & 0,0012 & $-0,0209$ & 0,0360 & 0,0159 \\
\hline $\mathrm{t}+4$ & 0,0039 & $-0,0240$ & 0,0550 & 0,0198 \\
\hline $\mathrm{t}+5$ & $-0,0030$ & $-0,0255$ & 0,0247 & 0,0139 \\
\hline $\mathrm{t}(-1,0)$ & $-0,0081$ & $-0,0338$ & 0,0217 & 0,0161 \\
\hline $\mathrm{t}(-1,+1)$ & $-0,0050$ & $-0,0763$ & 0,1599 & 0,0601 \\
\hline $\mathrm{t}(-5,+5)$ & $-0,0185$ & $-0,0782$ & 0,0739 & 0,0504 \\
\hline Source & $-0,0205$ & $-0,1012$ & 0,0520 & 0,0479 \\
\hline
\end{tabular}

Source: (processed data, 2020)

Analysis and Hypothesis test. In this study there are 4 hypotheses to be tested. This study uses one sample mean difference test to test hypotheses 1 and 2 (testing the existence of market reactions on announcements of changes in company listings (in and out) in the LQ 45 index, JII, and the SRI-Kehati Index, as related to hypothesis testing 3 and 4 (testing the difference in market reactions to announcements of changes in company listings (in and out) in the LQ 45 index, JII, and the SRI-Kehati Index), this study uses an independent $t$-test ( two sample mean differences ).

Based on the results of testing the data in table 10, it appears that in the group of companies included in the LQ 45 Index, the value of $t$ count from the period $t-5$ to $t+5$ (per period) nothing exceeds the t table value of 1,664 (using alpha 5\%, one side). The same result also occurs when using the cumulative window period $(\mathrm{t}-1,0 ; \mathrm{t}-1,+1 ; \mathrm{t}-1,+5 ; \mathrm{t}-5,+$ $5)$. However, at the time of the announcement of the company's entry into the LQ45 Index $(\mathrm{t} 0)$, the value of $\mathrm{t}$ statistic amounted to 1.6634 is greater than $\mathrm{t}$ table statistics. This indicates that there is a positive market reaction to the announcement of the company's entry into the LQ45 Index. In the case of a group of companies included in JII, a significant and varied market reaction was seen on several days of events. At $t-4$ and $t+3$ there are negative market reactions with $\mathrm{t}$ values of -2.0047 and -1.8435 (greater than $\mathrm{t}$-value of -1.782 ). As for $\mathrm{t}-2, \mathrm{t}$ +1 , and $t+2$ it was proven that there was a significant positive market reaction with $t$ value of 1.8739 each; 3.8854; and 2.8334 (greater than $t$ value of table +1.782). Even though when viewed per period there are various market reactions, if the cumulative window period is used $(\mathrm{t}-1,0 ; \mathrm{t}-1,+1 ; \mathrm{t}-1,+5 ; \mathrm{t}-5,+5)$, it appears that there is a reaction consistent market, which is a significant positive where $t$ count is greater than $t$ table. In the case of groups of companies included in the SRI-KEHATI Index, there was no significant market reaction during the period $t-5$ to $t+5$. Even if we use a significance of $10 \%$ there is a significant negative market reaction at $\mathrm{t}+2$, if the cumulative window period is used $(\mathrm{t}-1,0 ; \mathrm{t}-1,+1$; $\mathrm{t}$ $1,+5 ; \mathrm{t}-5,+5)$, it appears that there is no significant market reaction because the calculated 
$\mathrm{t}$ value is smaller than the $\mathrm{t}$ table value.

Table 10.

One Sample Mean Difference Test Results

Abnormal Returns on Companies Included in the LQ45 Index, JII, and SRI-Kehati

Index for the period 2009-2018

\begin{tabular}{c|c|c|c}
\hline \multirow{2}{*}{ Period } & \multicolumn{3}{|c}{ t score } \\
\cline { 2 - 4 } & LQ45 Index & JII & SRI-Kehati Index \\
\hline $\mathrm{t}-5$ & 0,0312 & $-1,5315^{*}$ & $-0,5605$ \\
\hline $\mathrm{t}-4$ & 0,3763 & $-2,0047^{* *}$ & $-0,2408$ \\
\hline $\mathrm{t}-3$ & 0,4564 & $-0,9039$ & 0,6231 \\
\hline $\mathrm{t}-2$ & $-1,3435$ & $1,8739^{* *}$ & 0,5029 \\
\hline $\mathrm{t}-1$ & $-1,0988$ & $-0,4119$ & 0,1727 \\
\hline $\mathrm{t} 0$ & $1,6634 *$ & $1,6711^{*}$ & $-0,7990$ \\
\hline $\mathrm{t}+1$ & 0,4664 & $3,8854^{*}$ & $-0,2396$ \\
\hline $\mathrm{t}+2$ & 1,0197 & $2,8334^{*}$ & $-1,3964 *$ \\
\hline $\mathrm{t}+3$ & 0,8313 & $-1,8435^{* *}$ & 0,1759 \\
\hline $\mathrm{t}+4$ & 0,4231 & 1,1440 & $-0,1785$ \\
\hline $\mathrm{t}+5$ & $-0,4382$ & 0,4790 & 0,1874 \\
\hline $\mathrm{t}(-1,0)$ & 0,3992 & $3,6378^{* * *}$ & $-0,4429$ \\
\hline $\mathrm{t}-(1,+1)$ & 0,5953 & $2,9702^{* * *}$ & $-0,4999$ \\
\hline $\mathrm{t}(-1,+5)$ & 1,0836 & $2,9320^{* * *}$ & $-0,7852$ \\
\hline $\mathrm{t}(-5,+5)$ & 0,7198 & $1,5652^{*}$ & $-0,5284$ \\
\hline
\end{tabular}

Source: (processed data, 2020)

Based on the results of testing the data in table 11, it appears that in the group of companies out of the LQ 45 Index, there was a significant negative market reaction in the t1 period where the t-value of -2.1031 was more negative than the t-table value of -1.664 . However, at the period e $t+5$ there was a significant positive market reaction where the value of $t$ count +2.0603 was greater than the value of $t$ table -1.664 (using $\alpha=5 \%$ ). This indicates that there is a positive market reaction. Even though when viewed per period there are various market reactions, if the cumulative window period is used $(\mathrm{t}-1,0 ; \mathrm{t}-1,+1 ; \mathrm{t}-1,+$ $5 ; \mathrm{t}-5,+5)$, it appears that there is a reaction The negative market is significant in the period $\mathrm{t}-1,+1$ where the value of $\mathrm{t}$ is equal to -1.6027 (using $\alpha=10 \%$ ) more negative than the value of t table -1.292. In the case of a group of companies that left JII, there was a significant and varied market reaction on several days of events. At $t-5$ there is a positive and significant market reaction with $t$ value as $r+2,2209$ (greater than $t$ value of table -1,687). As for the $t$ 1 period, it was proven that there was a significant negative market reaction with a t value of -1.7904 (more negative than the $t$ value of table -1.687). Even though when viewed per period there are various market reactions, if the cumulative window period is used $(\mathrm{t}-1,0 ; \mathrm{t}-$ $1,+1 ; \mathrm{t}-1,+5 ; \mathrm{t}-5,+5)$, it appears that there is a reaction consistent market, i.e. significant negative where $t$ count value is more negative than $t$ table value ( using $\alpha=10 \%$ ).

In the case of the group of companies that left the SRI-KEHATI Index, it was seen that there was a significant negative market reaction in the $t+2$ period where the $t$ value of -2.3905 was more negative than the $t$ table value of -1.782 . Even if we use a significance of $10 \%$ there is a significant positive market reaction at $\mathrm{t}-2$ where the calculated $\mathrm{t}$ value of +1.4162 is greater than the $t$ table value of +1.3356 , if the cumulative window period is used 
$(\mathrm{t}-1.0 ; \mathrm{t}-1,+1 ; \mathrm{t}-1,+5 ; \mathrm{t}-5,+5)$, it appears that there is a significant negative market reaction because the value of $t$ is more negative than the value of $t$ table. (in the period $t-1,+5$, the calculated $t$ value of -1.4648 is more negative than the $t$ table value of -1.3356 using right $\alpha$ $=10 \%$ ).

Table 11.

One Sample Mean Difference Test Results

Abnormal Returns on Companies Excluded from the LQ45 Index, JII, and SRI-Kehati Index for the period 2009-2018

\begin{tabular}{c|c|c|c}
\hline \multirow{2}{*}{ Period } & \multicolumn{3}{|c}{ t score } \\
\cline { 2 - 4 } & LQ45 index & JII & SRI-Kehati Index \\
\hline $\mathrm{t}-5$ & $-1,2036$ & $2,2209 * * *$ & 0,0314 \\
\hline $\mathrm{t}-4$ & 1.1265 & 0.6952 & $-0,3733$ \\
\hline $\mathrm{t}-3$ & 1.1230 & $-1,1262$ & $-0,1893$ \\
\hline $\mathrm{t}-2$ & $-0,1742$ & -0.4112 & $1.4162 *$ \\
\hline $\mathrm{t}-1$ & $-0,1907$ & $-1,7904 * *$ & $-0,1191$ \\
\hline $\mathrm{t} 0$ & $-0,4822$ & $-0,5406$ & $-1,3930 *$ \\
\hline $\mathrm{t}+1$ & $-2,1031 * * *$ & -0.4230 & .3834 \\
\hline $\mathrm{t}+2$ & 0.2124 & $-0,9779$ & $-2,3905 * * *$ \\
\hline $\mathrm{t}+3$ & $-0,8689$ & 0.6925 & -0.1807 \\
\hline $\mathrm{t}+4$ & $-0,8100$ & $-0,6546$ & 0.3068 \\
\hline $\mathrm{t}+5$ & $2,0603 * * *$ & 1,1153 & $-0,4825$ \\
\hline $\mathrm{t}(-1,0)$ & -0.4758 & $-1,6483 *$ & $-1,0693$ \\
\hline $\mathrm{t}-(1,+1)$ & $-1,6027 *$ & $-1,5900 *$ & $-0,6517$ \\
\hline $\mathrm{t}(-1,+5)$ & $-0,8248$ & $-0,9747$ & $-1,4648 *$ \\
\hline $\mathrm{t}(-5,+5)$ & $-0,3951$ & $-0,3619$ & $-0,9017$ \\
\hline
\end{tabular}

Based on the test results in table 12, the comparison of groups of companies included in the LQ45 and JII Indexes, shows that there are significant differences in market reactions in periods $\mathrm{t}-2, \mathrm{t}+1$, (using $\alpha=5 \%$ ) and $\mathrm{t}+5$ (using $\alpha=10 \%$ ) where the calculated $\mathrm{z}$ value is greater than the $z$ table value of 1.96 (1.65 if using $\alpha=10 \%$ ). Specifically the results of the study indicate that the market reaction for companies included in JII is greater than companies that enter the LQ45 Index.

In the comparison of the company's market reactions included in the LQ45 Index and the SRI-KEHATI Index as well as the comparison of the company's market reactions included in the JII and the SRI-KEHATI Index, it can be seen in the results of testing table 12 that there is no significant difference in market reactions where the $\mathrm{z}$ value is calculated statistically smaller than the table's $\mathrm{z}$ value. When using cumulative observations from the period $\mathrm{t}-5$ to $\mathrm{t}+5$, it can be seen that there is no difference in market reactions between companies included in the LQ45 and JII Indexes, the LQ45 Index and the SRI-KEHATI Index, and JII and the SRI-KEHATI Index where values $\mathrm{z}$ count is smaller than the table $\mathrm{z}$ value. 
Table 12.

Independent Mean Difference Test Results

Abnormal Returns on Companies Included in the LQ45 Index, JII, and SRI-Kehati Index for the period 2009-2018

\begin{tabular}{c|c|c|c}
\hline \multirow{2}{*}{ Periode } & \multicolumn{3}{|c}{ t score } \\
\cline { 2 - 4 } & LQ 45 \& JII & LQ 45 \& SRI-Kehati & JII \& SRI-Kehati \\
\hline $\mathrm{t}-5$ & $-0,2695$ & 0,9162 & 0,9626 \\
\hline $\mathrm{t}-4$ & 1,0427 & 0,9639 & 0,7639 \\
\hline $\mathrm{t}-3$ & 0,9378 & 0,8866 & 0,7174 \\
\hline $\mathrm{t}-2$ & $-3,4430^{* * *}$ & 0,4717 & 1,1589 \\
\hline $\mathrm{t}-1$ & $-0,8449$ & 0,7739 & 0,9199 \\
\hline $\mathrm{t} 0$ & $-0,4114$ & 1,2619 & 1,3466 \\
\hline $\mathrm{t}+1$ & $-2,4735^{* *}$ & 0,9097 & 1,4373 \\
\hline $\mathrm{t}+2$ & $-1,0295$ & 1,3333 & 1,6064 \\
\hline $\mathrm{t}+3$ & 1,3086 & 1,0110 & 0,6735 \\
\hline $\mathrm{t}+4$ & $-1,0055$ & 1,0634 & 1,2751 \\
\hline $\mathrm{t}+5$ & $-1,7757^{*}$ & 0,6781 & 1,0560 \\
\hline $\mathrm{t}(-5,+5)$ & $-0,9510$ & 0,9564 & 1,1070 \\
\hline $\mathrm{S} 0 u \mathrm{c}:(\mathrm{p}$ & & &
\end{tabular}

Source: (processed data, 2020)

As test results in Table 13, in comparison column reaction out of the enterprise market and JII LQ45 Index, shows that there are different reactions in the market where the value of $\mathrm{z}$ count is greater than the value of $\mathrm{z}$ table in period $\mathrm{t}-5$ and $\mathrm{t}-3$. The results vary in the period $\mathrm{t}-5$, the market reaction for companies leaving JII is greater than the companies leaving the LQ45 Index, whereas in t-3 the market reaction for companies leaving the LQ45 Index is greater than the companies leaving from JII.

In the comparison of the company's market reaction that came out of the LQ45 Index and the SRI-KEHATI Index and the comparison of the company's market reaction that came out of JII and the SRI-KEHATI Index, it can be seen in the test results of table 5.13 that there was no significant difference in the market reaction where $\mathrm{z}$ values are statistically calculated smaller than the table's $\mathrm{z}$ value. When using cumulative observations from the period $\mathrm{t}-5$ to $\mathrm{t}+5$, it can be seen that there is no difference in market reactions between companies leaving the LQ45 and JII Indexes, the LQ45 Index and the SRI-KEHATI Index, and JII and the SRI-KEHATI Index where values $\mathrm{z}$ count is smaller than the table $\mathrm{z}$ value.

Table 13.

Independent Mean Difference Test Results

Abnormal Returns on Companies Excluded from the LQ45 Index, JII, and SRI-Kehati Index for the period 2009-2018

\begin{tabular}{c|c|c|c}
\hline \multirow{2}{*}{ Periode } & \multicolumn{3}{|c}{ t hitung } \\
\cline { 2 - 4 } & LQ 45 \& JII & LQ 45 \& SRI-Kehati & JII \& SRI-Kehati \\
\hline $\mathrm{t}-5$ & $-1,9729 * *$ & $-0,0282$ & 1,5553 \\
\hline $\mathrm{t}-4$ & 0,0928 & 1,1186 & 0,9137 \\
\hline $\mathrm{t}-3$ & $2,6474 * * *$ & 1,3724 & $-0,8812$ \\
\hline $\mathrm{t}-2$ & 1,0323 & $-0,7858$ & $-1,4523$ \\
\hline
\end{tabular}




\begin{tabular}{c|c|c|c}
$\mathrm{t}-1$ & 1,4750 & 0,2567 & $-1,3093$ \\
\hline $\mathrm{t} 0$ & $-0,3004$ & 0,1681 & 0,6834 \\
\hline $\mathrm{t}+1$ & $-0,6141$ & $-0,5587$ & $-0,3407$ \\
\hline $\mathrm{t}+2$ & 1,1632 & 1,6381 & 1,1724 \\
\hline $\mathrm{t}+3$ & $-0,9640$ & $-0,9811$ & $-0,0595$ \\
\hline $\mathrm{t}+4$ & 0,1907 & $-0,7356$ & $-1,0118$ \\
\hline $\mathrm{t}+5$ & 0,3278 & 1,2189 & 0,9370 \\
\hline $\mathrm{t}(-5,+5)$ & 0,2205 & 0,6663 & 0,4610
\end{tabular}

Source: (processed data, 2020)

\section{DISCUSSION}

This study aims to determine market reaction to the announcement of company list changes in an index at Indonesian Capital Market. Specifically, this study will examine the market's reaction to the announcement of company list change's at the LQ45 Index, the Jakarta Islamic Index (JII), and the SRI-KEHATI Index. In addition, this study also intends to examine whether there are differences in market reactions between companies that enter and exit the LQ45 Index, JII, and the SRI-Kehati Index. Table 10 shows that in the group of company shares included in the index, a significant positive market reaction only occurred in the group of company shares included in JII, while company shares included in the LQ45 Index and the SRI-Kehati Index did not find any positive market reaction. The positive market reaction to company shares included in JII is in line with the results of Sayani and Balakrishnan's (2013) research which found that there was a positive market return and lower volatility when the company entered into the Islamic Index (KMI30) on the Karachi Stock Exchange.

Associated with the sample of companies included in the SRI-Kehati Index, even though using cumulative abnormal returns it is seen that there is no significant positive market reaction, when using abnormal returns with testing per day during the test period, it appears that at $t+2$ there is a negative reaction and significant (at $\alpha=10 \%$ ). These results are in line with the results of the Oberndorfer et al (2013) study which found that there were significant negative market reactions for companies included in the SRI Index on the German capital market. Oberndorfer et al (2013) explained the results of the study showed that investors in the German capital market assumed that the inclusion of companies in the SRI index had no economic impact on the company's financial performance. Table 11 shows that in the group of shares of companies out of the LQ45 Index, JII, and the SRI-Kehati Index a significant negative market reaction was found. This result shows that the market reacts more to negative information, in which case the exit of the company from the Index is perceived as a negative signal of the company's inability to meet the criteria set by each Index. The results of this study are in line with research by Papachristou et al. (2018) who found that the market reaction to the shares of companies that came out of the FTSE-ASE20 Index (Athens Stock Exchange) was more prominent than the company's stocks that entered the index. Specifically, Papachristou et al. (2018) found that a significant negative market reaction lasted longer (longer) than a positive market reaction on companies that entered into the Index (took place in a short time). Although the results of this study indicate that there was a significant negative market reaction to the announcement company shares are out of the Index, but the significance level of the market reaction is relatively low (only 
significant at $\alpha=10 \%$ when looking at cumulative abnormal returns ). As for the group of company shares included in the Index, it is generally seen that the market does not react (only on company shares included in JII). These results are not much different from the study of Qiu and Pinfold (2007) who found that in general there was no significant market reaction for companies entering and leaving the ASX100 Index (Australia Stock Exchange). Qiu and Pinfold (2007) explain that the results of their research are consistent with previous studies which found that market reactions to shares of companies that enter and exit the Index in other countries are relatively lower than market reactions to shares of companies that enter and exit the Index in the United States (US).

Table 12 and table 13 in general show that there are no significant differences in market reactions (both in companies that enter and exit) between the LQ45 Index, JII, and the SRI-Kehati Index. Significantly different market reactions were only found in companies that entered and exited the LQ45 and JII Indexes. In line with the results in table 10 and table 11, a significant positive (negative) reaction to the company's shares coming in (out) only occurs consistently on JII. There is no significant market reaction for companies that enter (exit) from the LQ45 Index, perhaps because the information asymmetry in companies in the LQ45 index is relatively low because these companies have relatively large market capitalization, high trading volume so that the stock is better known by the public (investor). Meanwhile, there is no significant market reaction to companies that enter (exit) from the SRI-Kehati Index, it might be caused because the market thinks that companies that are in the SRI category are not optimal to be included in the portfolio because companies included in the SRI Index have investment costs in Relatively large CSR (cost).

\section{CONCLUSION}

This study tries to test the market reaction to company announcements that enter and exit the LQ45 Index, JII, and SRI-KEHATI Index. In addition, this study also intends to examine the differences in market reactions between announcements of companies entering and exiting between the LQ45 Index, JII, and the SRI-KEHATI Index. Based on the test results in this study, it can be concluded as follows: There is no market reaction to the announcement of companies that enter the LQ45 Index; There was a significant positive market reaction to the announcement of companies that entered into JII ; There was no market reaction to company announcements included in the SRI-KEHATI Index; There was a significant negative market reaction to company announcements coming out of the LQ45 Index; There was a significant negative market reaction to company announcements leaving JII; There was a significant negative market reaction to company announcements leaving the SRI-KEHATI Index; There are significant differences in market reaction to company announcements included in the LQ45 and JII Indexes; There is no significant difference in market reaction on the announcement of companies that enter the LQ45 Index and the SRIKEHATI Index, and companies that enter into the JII and SRI-KEHATI Index; There is a significant difference in market reaction on announcements of companies leaving the LQ45 and JII Indexes, and there is no significant difference in market reactions on announcements of companies leaving the LQ45 Index and the SRI-KEHATI Index, and companies that leave JII and the SRI-KEHATI Index .

The results of the study are useful to investors in making investment decision on the announcement of changes to the list of companies that go in and out of the index in the 
capital markets . Based on the results of the study, investors need to pay attention to information on the release of a stock from the capital market index because this research found that the market reacts more to the information on the exit of a company's stock ( $\mathrm{bad}$ news ) compared to information on the entry of a company's stock into the index ( good news ).

As for, here are some inputs for further research: Related to determining the date of the announcement, it is recommended that further research use the announcement date rather than the date of implementation of the activity (this is intended to obtain more accurate test results which actually capture the market reaction at the time of the announcement); related to the determination of the company sample beta, correction beta should be used (this is intended to avoid the effects of thin trading ( thin trading ) which can have an impact on the bias of the estimated beta company obtained); In relation to company samples in the SRIKEHATI Index, it takes even longer periods to obtain more samples (this is intended to increase the statistical power of research results); Future studies can further test the factors that influence (explain) market reactions on companies that enter (exit) from the Index by using several hypothetical approaches (approaches) such as price pressure, downwardsloping demand curves, improved liquidity, improved operating performance, and the increased investor awareness hypothesis as studied in Elliott et al (2006) and Chen et al (2004). As for Marciniak and Smith (2018), using factors in the form of a degree of uncertainty in the condition of the company (proxied by market market capitalization of the company relative to the Index, trading volume of the company's shares, first entered in the Index) and the market to explain the market reaction to the announcement of the company's entry in the Index; and further research can compare market reactions using subsample periods that focus on certain important events. For example in the study of Kamal et al (2011), they compared the market reactions of companies included in the S\&P 500 Index before and after 2000 . The results of the study showed that there were significant reaction differences in which market reactions to announcements of companies entering the S\&P 500 Index after years 2000 was smaller than before 2000. This was caused because after 2000, a fair fair disclosure (FD), decimalization , and Sarbanes Oxley Act was stipulated which caused the level of asymmetry of company information to decrease (as a result of disclosure of information to the public).

\section{REFERENCES}

Bennett, Michael.S. dan Zamir Iqbal.(2013). How Socially Responsible Investing Can Help Bridge The Gap Between Islamic And Conventional financial Markets. International Journal of Islamic and Middle Eastern Finance and Management; Vol.6, No.3, pp. 211-225.

Biktimirov, Ernest N. Dan Li, Boya. (2014). Asymmetric Stock Price and Liqudity Responses to Changes in the FTSE SmallCap Index. Review of Quantitative Finance and Accounting, Vol. 42, No.1, pp. 95-122.

Biktimirov, Ernest N. dan Xu, Yuanbin. (2019). Market Reactions to Change in the Dow Jones Industrial Average Index. International Journal of Managerial Finance, Vol. 15, No.5, pp. 792-812.

BinMahfouz, Saeed dan M. Kabir Hassan. (2013). Sustainable and Socially Responsible Investing : Does Islamic Investing Make A Difference?. Humanomics. Vol. 29. Issue 
: 3. pp 164-186. DOI : 10.1108/H-07-2013-0043.

Bousalam, Issam dan Moustapha Hamzaoui. (2016). Impact of Ethical Screening on Risk and Returns : The Case of Constructed Moroccan Islamic Stock Indices. Journal of Financial Regulation and Compliance. Vol. 24. Issue : 3. pp : 268-291. DOI : 10.1108/JFRC-01-2016-0002.

Chen, Honghui, Noronha, Gregory, dan Singal, Vijay. (2004). The Price Response to S\&P 500 Index Additions and Deletions: Evidence of Asymmetry and A New Explanation. The Journal of Finance, Vol. 59, No. 4, pp. 1901-1929.

Denis, Diane K., McConnell, John J., Ovtchinnikov, Alexei V., dan Yu, Yun. (2003). S\&P 500 Index Additions and Earnings Expectations. The Journal of Finance, Vol. LVIII, No.5, pp 1821-1840.

Diaz, John Francis. T. (2016). Return And Volatility Performance Comparison Of Ethical And Non-Ethical Publicly-Listed Financial Services Companies. Ethics and Economics, Vol, 13, No. 1. http://ethique- economique.net/

Elliott, William B; Ness, Bonnie F. Van, Walker, Mark D; Warr, Richard S. (2006). What Drives the S\&P 500 Inclusion Effect? An Analytical Survey. Financial Management, Vol. 35, No. 4, pp. 31-48.

Ghozali, H. Imam. (2011). Aplikasi Analisis Multivariate dengan Program IBM SPSS 19: Edisi 5. Badan Penerbit Universitas Diponegoro.

Heriyanto; Kewal, Suramaya Suci; dan Bernadus, Yohanes Andri Putranto. (2019). Socially Responsible Investing (SRI) dan Kinerja Saham. Jurnal Nominal, Vol. VIII, No.2, pp. 194-208.

Hrazdil, Karel dan Scott, Thomas. (2009). S\&P 500 Index Revisited: Do Index Inclusion Announcements Convey Information about Firm's Future Performance? Quarterly Journal of Finance and Accounting, Vol. 48, No. 4, pp. 79-113.

Josev, Thomas, Chan Horward, dan Faff, Robert. (2004). What's in a Name? Evidence on Corporate Name Changes from the Australian Capital Market. Pacific Accounting Review, Vol. 16, No.1

Kamal, Rashiqa; Lawrence, Edward R.; McCabe, George; Prakash, Arun J. (2011). Additions to S\&P 500 Index: not so informative any more. Managerial Finance, Vol. 38 No. 4, pp. 380-402.

Karim, Khendkar, Sanghyun Suh dan Jiali Tang. (2016). Do Ethical Firms Create Value? Social Responsibility Journal. Vol.12. Issue : 1. pp : 54-68. DOI : 10.1108/SRJ-092014-0127.

Marciniak, Marek dan Smith, Deborah Drummond. (2018). Does market response to S\&P additions reflect adjustment for risk?. The Journal of Risk Finance, Vol. 19 No. 5, pp. 437-453.

Marciniak, Marek. (2012). Information Effects of Announced Stock Index Additions: Evidence From S\&P 400. Journal Economic Finance, Vol. 36, pp. 822-849.

Mazouz, Khelifa, Mohamed, Bdulkadir, dan Saadouni, Brahim. (2019). Price Reaction of Ethically Screened Stocks: A Study of The Dow Jones Islamic Market World Index. Journal of Business Ethics, Vol. 154, No.3, pp. 683-699.

Oberndorfer, Ulrich; Schmidt, Peter; Wagner, Marcus; Ziegler, Andreas. (2013). Journal of Environmental Economics and Management, No. 66, pp. 497-509.

Okada, Katsuhiko, Isagawa, Nobuyuki, dan Fujikawa, Kenya. (2006). Addition to the Nikkei 225 Index and Japanese Market Response: Temporary Demand Effect of 
Index Arbitrageurs. Pacific-Basin Finance Journal, Vol. 14, No.4, pp. 395-409.

Papachristou, George; Papadamou, Stephanos, dan Spyromitros, Eleftherios. (2018). Asymmetric price responses to stock addition to and deletion from the Athens Stock Exchange Index. Managerial Finance, Vol. 44 No. 4, pp. 406-423.

Qiu, Mei and Pinfold, John. (2007). Price and trading volume reactions to index constitution changes. Managerial Finance, Vol. 34, No. 1, pp. 53 - 69.

Sayani, Hameedah; Balakrishnan, Melodena Stephens. (2013). Marketing an Islamic index: perceived value of KMI30 Index. Management Research Review, Vol. 36, No. 4, pp. $326-358$.

Tandelilin, E. (2010). Portofolio dan Investasi Teori dan Aplikasi, Edisi Pertama. Kanisius: Yogyakarta.

Yu, Susana, Webb, Gwendolyn, dan Tandon, Kishore. (2015). What Happens When A Stock is Added to The Nasdaq-100 Index? What doesn't happen? Managerial Finance, Vol. 41, No. 5, pp. 480-506. 